\title{
Mariusz Miąsko
}

Kancelaria Prawna Viggen Sp.j.

\section{ANALIZA CHARAKTERYSTYKI UMOWY O POMOCY PRZY ZBIORACH (UJĘCIE KOMPARATYSTYCZNE)}

\begin{abstract}
Contract of help by harvests - comparative analysis

The subject of the analysis was a new contract in polish legal system - the contract of help by harvests - and sources of motivation to create this agreement. The goal of research was particularly the answer on question: why contract of help by harvests was legally defined as civil law contract, despite of fact that it has all essential attributes, which are relevant to contract of work.

Słowa kluczowe: umowa o pomocy przy zbiorach, ubezpieczenie społeczne rolników, prawo rolne, prawo pracy, umowa cywilnoprawna, nowy typ umowy, zbiory produktów rolnych

Key words: contract of help by harvests, social insurance of farmers, agricultural law, labour law, contract of civil law, new type of contract, harvests

\section{Nowy rodzaj umowy}

Parlament w wyniku starań środowisk rolniczych, a w szczególności NSZZ Rolników Indywidualnych „Solidarność”, przegłosował nowelizację Ustawy o ubezpieczeniu społecznym rolników ${ }^{1}$, powołującej do życia umowę o pomocy przy zbiorach. Ustawa weszła w życie w maju br. i już narosły wokół niej wątpliwości, artykułowane przez NSZZ „Solidarność, a także Centralny Instytut Ochrony Pracy oraz Główny Inspektorat Pracy. Warto więc, dokonać pogłębionej analizy cech przedmiotowej umowy, jej umiejscowienia w systemie prawnym, także w kontekście praw człowieka, oraz wpływu, jaki może wywierać na środowiska pracowników i pracodawców, w szczególności zaś skutków dla systemu ubezpieczeń społecznych i Skarbu Państwa.
\end{abstract}

${ }^{1}$ Ustawa z dnia 13 kwietnia 2018 r. o zmianie ustawy o ubezpieczeniu społecznym rolników oraz niektórych innych ustaw, Dz. U. 2018, poz. 858, http://prawo.sejm.gov.pl/isap.nsf/DocDetails. xsp?id=WDU20180000858 (dostęp: 17.06.2018). 


\section{Szczególna rola umowy o pomocy przy zbiorach}

Na potrzeby oceny rzeczonej umowy rzutować musi jej zakres funkcjonalny. Podstawową racją przemawiającą za potrzebą opracowania nowego rodzaju umowy był brak w systemie prawnym elastycznej konstrukcji, dopasowanej charakterystyką do specyfiki pracy w rolnictwie, która pozwoliłaby zatrudnić relatywnie niedrogo i jednocześnie legalnie pracowników do zbiorów lub czynności, które z uwagi na warunki pogodowe (ogólnie ujmując vis maior) czyniłyby niektóre wybrane rodzaje produkcji rolnej - nierentownymi. Brak takowej umowy prowadził zbyt często do zaniechania hodowli niektórych upraw lub likwidacji już wyprodukowanych płodów rolnych, jeszcze przed ich zebraniem.

Na przykład warto zauważyć, iż dynamika dojrzewania produktów rolnych jest tak duża, że zbiór np. truskawek w ciągu kilku godzin po optymalnym terminie wywołuje ich przejrzewanie i gwałtowny spadek wartości (często nawet o 70-90\%). W odróżnieniu od innych działów gospodarki $\mathrm{w}$ rolnictwie $\mathrm{z}$ uwagi na warunki pogodowe nie ma realnej możliwości pełnego planowania czasu zbioru, czynności pielęgnacyjnych itp. Niektóre czynności można wykonać jedynie za pomocą wykorzystania zmasowanej siły pracowników. W konsekwencji w warunkach zastosowania innych („drogich”) typów umów dochodziło nader często do zaniechania zbioru już wyprodukowanych płodów rolnych i ich zniszczenia, co wydaje się zarówno nieracjonalne, jak i ze wszech miar etycznie co najmniej wątpliwe. Produkty przejrzałe można bowiem zagospodarować np. na przetwory, o ile istnieje tylko ekonomiczne uzasadnienie ich zbioru.

Dokonując oceny zasadności wprowadzenia przedmiotowej umowy do polskiego systemu prawnego, nie sposób pominąć aktualnej sytuacji na rynku pracy. Projekt nowelizacji ustawy powołującej umowę o pomocy powstał w warunkach poważnego niedoboru pracowników mogących świadczyć prace na potrzeby sektora rolniczego. Umowa powstała w warunkach rekordowo niskiego bezrobocia w Polsce, zwłaszcza na obszarach wiejskich (na których populacja rolników skurczyła się z naturalnych przyczyn demograficznych). Umowa została opracowana w odpowiedzi na niezwykle wysokie zapotrzebowanie na siłę roboczą spoza Unii Europejskiej (głównie z Ukrainy), a więc w realiach swoistego stanu wyższej konieczności, co rzutuje wprost na jej cechy.

\section{Nazwa i zakres umowy}

Dla porządku należy nadmienić, że gdyby szukać analogii do nazw innych umów cywilnoprawnych, np. „umowy o dzieło”, „umowy zlecenia”, to być może zręczniej byłoby użyć nazwy „umowa o pomoc przy zbiorach” zamiast „umowa o pomocy przy

2 Ustawa z dnia 23 kwietnia 1964 r. Kodeks cywilny, Dz. U. 1964, Nr 16, poz. 93, http://prawo.sejm. gov.pl/isap.nsf/DocDetails.xsp?id=WDU19640160093 (dostęp: 17.06.2018). 
zbiorach"3. Jest to jednak uwaga natury semantycznej, niewpływająca na ocenę samej konstrukcji umowy i jej skutków.

Strony mogą zawrzeć umowę o pomocy wyłącznie w odniesieniu do prac polegających na zbiorach i innych wyraźnie wskazanych w ustawie ${ }^{4}$ czynności występujących przy produkcji owoców i warzyw, chmielu, tytoniu, ziół i roślin zielarskich.

Znacznie istotniejsza od semantyki jest okoliczność, że nazwa umowy w zawężony sposób oddaje zakres przedmiotowy, wynikający z treści art. 91a ust. 2 Ustawy o ubezpieczeniu społecznym rolników (UoUSR). Umowa znajduje bowiem zastosowanie oprócz „zbiorów” także do takich czynności: usuwania zbędnych części roślin, klasyfikowania zebranych produktów rolnych, sortowania zebranych produktów rolnych, wykonywania innych czynności mających na celu przygotowanie zebranych produktów rolnych do transportu, wykonywania innych czynności mających na celu przygotowanie zebranych produktów rolnych do przechowywania, wykonywania innych czynności mających na celu przygotowanie zebranych produktów rolnych do sprzedaży, pielęgnowania i poprawy jakości plonów.

Trudno jednak w dychotomii nazwy i zakresu przedmiotowej umowy dopatrywać się jakichkolwiek daleko idących wniosków. Nazwa oddaje bowiem główną intencję usytuowania w polskim porządku prawnym typu umowy nakierunkowanej na „zbiór”, z którym związane są inne dodatkowe czynności. Zbiór płodów rolnych pozostaje w ścisłej korelacji z wieloma innymi czynnościami „okołozbiorowymi”. Gdyby jednak chcieć w sposób bardziej doskonały oddać intencję nazwy umowy, to być może powinna ona brzmieć: Umowa o pomocy w warunkach przesilenia i chwilowego nadzwyczajnego zapotrzebowania na prace w rolnictwie. Taka jest bowiem jej podstawowa rola. Elastyczna konstrukcja umowy w znaczący sposób oddaje istotę chwilowego spiętrzania się prac $\mathrm{w}$ tych działach rolnictwa, w których pracy nie da się wykonać zarówno $\mathrm{z}$ wykorzystaniem urządzeń rolniczych, jak i z zastosowaniem chemii, i praca musi byś krótkookresowo wykonana wyłącznie z wykorzystaniem siły rąk ludzkich - w ściśle określonym czasie $\mathrm{z}$ uwagi na dynamikę dojrzewania lub zapotrzebowania na pielęgnację roślin.

\section{Adresaci i strony umowy}

Stronami umowy są: „,rolnik” $i$ „pomocnik rolnika”. W tym miejscu (pozorne) niejasności może budzić zarówno definicja „rolnika”, jak i „pomocnika rolnika”. Wątpliwość w kwestii zdefiniowania instytucji „,rolnika” wynika z wykładni systemowej i umiejscowienia umowy o pomocy przy zbiorach w UoUSR . Można by na tej podstawie wyciągnąć niesłuszny

${ }^{3}$ Argument taki wyartykułował także przedstawiciel Biura Legislacyjnego Senatu podczas obrad Komisji Rolnictwa 16 marca 2018 r.

${ }_{4}^{4}$ Art. 91a ust. 2 Ustawy z dnia 13 kwietnia 2018 r. o zmianie ustawy o ubezpieczeniu społecznym rolników oraz niektórych innych ustaw, Dz. U. 2018, poz. 858, http://prawo.sejm.gov.pl/isap.nsf/DocDetails. xsp?id=WDU20180000858 (dostęp: 17.06.2018). 
wniosek, iż objęci jej postanowieniami są jedynie rolnicy ubezpieczeni w KRUS 5 . Jako współautor projektu przedmiotowej umowy i uczestnik prac nad jej kształtem przy Ministerstwie Rolnictwa i Rozwoju Wsi mogę wyrazić spostrzeżenie, iż nie taka była jednak intencja podmiotów uczestniczących w długotrwałych (kilkunastomiesięcznych) konsultacjach między stroną rządową a społeczną ${ }^{6}$. Wyrazem intencji stron konsultacji w zakresie określenia adresatów umowy jest odwołanie się do definicji rolnika wyrażona w art. 6 UoUSR. Można więc przyjąć, że na potrzeby umowy o pomocy przy zbiorach przez rolnika rozumie się

osobę fizyczną, zamieszkującą i prowadzącą na terytorium Rzeczypospolitej Polskiej, osobiście i na własny rachunek, działalność rolniczą w pozostającym w jej posiadaniu gospodarstwie rolnym, w tym również w ramach grupy producentów rolnych,

ale jak już wcześniej nadmieniono, wyłącznie w zakresie produkcji roślinnej, w tym produkcji ogrodniczej, sadowniczej i zielarskiej.

Z tak rozumianej definicji „,rolnika” wynika, iż stroną umowy mogą być także rolnicy ubezpieczeni w ZUS, a także tzw. grupy producentów rolnych i ich związki .

Pewnych wątpliwości może nastręczać zakres podmiotowy „pomocnika”, przez którego rozumie się osobę pełnolet nią, z którą rolnik zawarł umowę pomocy przy zbiorach. Można zadać pytanie, czy pomocnikiem może być obywatel polski, ubezpieczony już wcześniej w systemie KRUS lub ubezpieczony w ZUS? Należy bowiem zwrócić uwagę, iż w praktyce niemalże wszyscy potencjalni pomocnicy będący obywatelami Polski, są już ubezpieczeni bądź to w ZUS, bądź w KRUS. Można więc się zastanowić, czy pracownik już podlegający pełnemu pakietowi ubezpieczeń społecznych (jako np. rolnik - sąsiad, wcześniej ubezpieczony w KRUS lub student albo inny pracownik zatrudniony i ubezpieczony w ZUS) może zostać dodatkowo doubezpieczony jako pomocnik? W praktyce pomocnikami w krótkoterminowych spiętrzeniach pracy w rolnictwie są właśnie sąsiedzi oraz inni pracownicy podlegający już ubezpieczeniu społecznemu w KRUS lub ZUS. Można wyrazić jednak pogląd, iż wątpliwości te wydają się nieuzasadnione, zważywszy, że sama Ustawa o ubezpieczeniu społecznym rolników nie czyni ograniczeń w przedmiotowym zakresie. Pomocnicy posiadający obywatelstwo polskie mogą de facto podlegać ubezpieczeniu w sposób zmultiplikowany (na podstawie zasadniczego ubezpieczenia w KRUS i ZUS oraz dodatkowego ubezpieczenia $\mathrm{z}$ tytułu wykonywania pracy w charakterze pomocnika). Dodatkowo w obrębie tego samego miesiąca na rzecz ubezpieczenia pomocnika zatrudnionego u wielu rolników wpłynie wielokrotnie pełna składka zdrowotna, pomimo że suma pracy w miesiącu stanowi constans,

5 Kasa Rolniczego Ubezpieczenia Społecznego.

6 Pierwsze konsultacje społeczne w Ministerstwie Pracy miały miejsce w marcu 2017 r., a pierwsze konsultacje w Ministerstwie Rolnictwa odbyły się w listopadzie 2018 r.

7 W rozumieniu Ustawy z dnia 15 września 2000 r. o grupach producentów rolnych i ich związkach oraz o zmianie innych ustaw, Dz. U. 2000, Nr 88, poz. 983. 
co de lege ferenda należałoby poddać modyfikacji jako być może nieusprawiedliwione namnożenie kosztów pracy występujących po stronie rolników (o ile same środowiska rolnicze zechcą kwestionować przedmiotowe regulacje).

\section{Przynależność umowy o pomocy przy zbiorach do gałęzi prawa}

Umowa o pomocy przy zbiorach, pomimo iż nosi wszelkie konstytutywne cechy stosunku pracy ${ }^{8}$, została zdefiniowana przez ustawodawcę jako umowa cywilnoprawna. Na próżno jednak jej szukać w Kodeksie cywilnym (kc), ponieważ umiejscowiona została w Ustawie o ubezpieczeniu społecznym rolników. Art. 91a ust. 4 wprost potwierdza jej cywilnoprawny charakter, stanowiąc, iż: „Wykonywanie czynności, o których mowa w ust. 2, na podstawie umowy o pomocy przy zbiorach nie stanowi zatrudnienia w rozumieniu Kodeksu pracy (kp)".

Rozwiązanie, w którym umowa cywilnoprawna nie została uregulowana wprost $\mathrm{w}$ kc, nie stanowi precedensu. Podobne bowiem rozwiązanie funkcjonuje w polskim prawie w odniesieniu do umów dotyczących usług opiekuńczych i bytowych ${ }^{9}$. Niesłuszny jest więc argument podnoszony przez pracownicze związki zawodowe, iż w ogóle nie ma w polskim porządku prawnym podobnych rozwiązań ${ }^{10}$.

\section{Analiza wybranych cech umowy o pomocy przy zbiorach}

Umowa o pomocy przy zbiorach pod wieloma względami może zostać uznana za osobliwość, zarówno na gruncie gałęzi prawa pracy, jak i prawa cywilnego. Nie jest jednak aż tak nietypową konstrukcją, jak stara się to przedstawić pracowniczy związek zawodowy NSZZ „Solidarność. Warto więc odnieść się kolejno do poszczególnych cech umowy o pomocy przy zbiorach:

1. Pełnoletniość. Pełnoletniość pomocnika stanowi konstytutywną cechę rzeczonej umowy, a przedmiotowy wymóg jest związany m.in. z charakterem pracy w rolnictwie, wynika z potrzeby zachowania podwyższonej ostrożności podczas prac lub z potencjalnie znacznego ciężaru przenoszonych produktów rolnych. Pełnoletniość pomocnika $\mathrm{z}$ założenia ma stanowić jeden z elementów podnoszących poziom bezpieczeństwa pracowników w pracy.

2. Osobiste świadczenie pracy. Wymóg ten, po pierwsze, ma na celu uniemożliwić powierzenie pracy innej osobie, np. niepełnoletniej, a ponadto przeciwdziała możliwości

${ }^{8}$ Art. 22 Kodeksu pracy, Dz. U. 1974, Nr 24, poz. 141, http://prawo.sejm.gov.pl/isap.nsf/download. xsp/WDU19740240141/U/D19740141Lj.pdf (dostęp: 7.06.2018).

${ }_{9}$ Umowy ustanowione na potrzeby prowadzenia rodzinnego domu pomocy na podstawie art. 52 Ustawy z dnia 12 marca 2004 r. o pomocy społecznej, Dz. U. z 2016 r., poz. 930.

10 Argument taki został podniesiony przez przedstawiciela pracowniczego związku zawodowego NSZZ „Solidarnośćc podczas konsultacji w pałacu Prezydenta RP w maju 2014 r. 
przekroczenia maksymalnego dopuszczalnego wymiaru 180 dni pracy w roku na warunkach przedmiotowej umowy.

3. Brak wymogu świadczenia płacy minimalnej. Umowa o pomocy przy zbiorach została zaprojektowana jako dwunasty rodzaj umowy w polskim porządku prawnym, do której nie mają zastosowania wymagania świadczenia pracownikowi płacy minimalnej. Można zauważyć, że na podstawie art. 8d Ustawy o minimalnym wynagrodzeniu za pracę $^{11}$ oblig świadczenia płacy minimalnej nie dotyczy także jedenastu innych umów: zlecenia ${ }^{12}$ lub o świadczenie usług ${ }^{13}$; grupy umów dotyczących usług opiekuńczych i bytowych, realizowanych poprzez prowadzenie rodzinnego domu pomocy ${ }^{14}$ : umowa o pełnienie funkcji rodziny zastępczej zawodowej, umowa o utworzeniu rodziny zastępczej zawodowej lub rodzinnego domu dziecka, umowa w przedmiocie prowadzenia rodzinnego domu dziecka, umowa w przedmiocie pełnienia funkcji rodziny pomocowej, umowa w przedmiocie pełnienia funkcji dyrektora placówki opiekuńczo-wychowawczej typu rodzinnego, umowa $\mathrm{w}$ przedmiocie pełnienia funkcji wychowawcy wyznaczonego do pomocy w kierowaniu placówką opiekuńczo-wychowawczą typu rodzinnego ${ }^{15}$; umowy dotyczące usług opieki domowej nad osobą niepełnosprawną, przewlekle chorą lub $\mathrm{w}$ podeszłym wieku, gdy w związku $\mathrm{z}$ ich wykonywaniem osoba świadcząca usługi zamieszkuje wspólnie z podopiecznym w jego mieszkaniu lub domu, umowa o dzieło.

Można więc zauważyć, iż umowa o pomocy w zbiorach plasuje się w grupie umów, co do których z uwagi na ich szczególny charakter nie ma ekonomicznych możliwości zastosowania uregulowań odnoszących się do świadczenia płacy minimalnej. W odmiennym przypadku z uwagi na nierentowność zbiorów, wobec gwałtownego spadku wartości przejrzewających produktów rolnych, częstokroć należałoby zaniechać zbiorów lub wykonywać je nielegalnie zupełnie bez umów bądź zniszczyć uprawy, ponosząc w niektórych przypadkach dodatkowy koszt utylizacji. Legislator polski wyszedł, jak się wydaje, ze słusznego założenia, iż taka sytuacja naruszałaby elementarne zasady etyczne lub motywowałaby do wykorzystywania nielegalnych form zatrudnienia, na czym finalnie traciliby pracownicy pozbawieni zabezpieczeń społecznych oraz KRUS bez wpływów, a także Skarb Państwa pozbawiony podatku dochodowego. W racjonalny sposób okresowe spiętrzenie prac w rolnictwie uznano za swoisty stan wyższej konieczności, wymagający

${ }^{11}$ Ustawa z dnia 22 lipca 2016 r. o zmianie ustawy o minimalnym wynagrodzeniu za pracę oraz niektórych innych ustaw, Dz. U. 2016, poz. 1265, 1986.

12 Art. 734 Kodeksu cywilnego (,jeżeli o miejscu i czasie wykonania zlecenia lub świadczenia usług decyduje przyjmujący zlecenie lub świadczący usługi i przysługuje mu wyłącznie wynagrodzenie prowizyjne").

${ }_{13}$ Art. 750 Kodeksu cywilnego (,jeżeli o miejscu i czasie wykonania zlecenia lub świadczenia usług decyduje przyjmujący zlecenie lub świadczący usługi i przysługuje mu wyłącznie wynagrodzenie prowizyjne").

${ }_{14}$ Zob. art. 52 Ustawy z dnia 12 marca 2004 r. o pomocy społecznej, Dz. U. z 2016 r., poz. 930.

${ }^{15} \mathrm{~W}$ przypadku gdy w tej placówce nie ma zatrudnionego dyrektora, umowy dotyczące usług polegających na sprawowaniu opieki nad grupą osób lub osobami podczas wypoczynku lub wycieczek - jeżeli ze względu na charakter sprawowanej opieki usługi są świadczone nieprzerwanie przez okres dłuższy niż 1 doba. 
nadzwyczajnego podejścia, uzasadniającego rezygnację z obowiązku świadczenia płacy minimalnej.

4. Objęcie pomocników uregulowaniami dotyczącymi BHP. Pomocnicy przy zbiorach w oczywisty sposób są objęci przepisami dotyczącymi Bezpieczeństwa i Higieny Pracy, i to w dwójnasób. Kwestie związane z BHP w rolnictwie są regulowane zarówno na gruncie lex generalis (art. $304 \$ 1 \mathrm{kp}$ ), jak i na podstawie branżowych uregulowań w rolnictwie o charakterze lex specialis (art. 63 ust. 2 Ustawy o ubezpieczeniu społecznym rolników).

Przede wszystkim kwestię uregulowań Bezpieczeństwa i Higieny Pracy rozstrzyga UoUSR, stanowiąc, iz:

Prezes Kasy w porozumieniu z Radą Rolników, ministrem właściwym do spraw zabezpieczenia społecznego, ministrem właściwym do spraw rozwoju wsi oraz ministrem właściwym do spraw zdrowia określa zasady ochrony zdrowia i życia w gospodarstwie rolnym. Zasady te są zaleceniami dotyczącymi wyposażenia gospodarstwa, zabezpieczenia osób pracujących oraz sposobu wykonywania czynności związanych z działalnością rolniczą, ustanowionymi w celu zapobiegania wypadkom przy pracy rolniczej i rolniczym chorobom zawodowym ${ }^{16}$.

Tak więc zasady BHP są ustalane przy współudziale aż pięciu instytucji (w tym trzech Ministerstw: Pracy, Rolnictwa, Zdrowia). Na tej podstawie KRUS emituje dokument „Zasady ochrony zdrowia i życia w gospodarstwie rolnym”.

Warto w tym miejscu zauważyć, że UoUSR postrzega obowiązek stosowania zasad BHP przez pryzmat "gospodarstwa rolnego”, a więc zasady BHP mają odniesienie do każdej osoby wykonującej pracę w rolnictwie (zarówno rolnika, jak i pomocnika oraz każdej innej osoby wykonującej pracę w gospodarstwie rolnym, niezależnie od jej formalnego statusu prawnego).

Niezależnie od powyższych uregulowań można wyrazić pogląd, iż regulacje dotyczące BHP ${ }_{w}$ gospodarstwach rolniczych w niektórych przypadkach podlegają także regulacjom Kodeksu pracy. Wynika to wprost z treści art. $304 \$ 1$ kp, stanowiącego, iż: „Pracodawca jest obowiązany zapewnić bezpieczne i higieniczne warunki pracy (...), osobom fizycznym wykonującym pracęna innej podstawie niż stosunek pracy w zakładzie pracylub w miejscu wyznaczonym przez pracodawcę (...)”.Z powyższego wynika, że rolnik będący przedsiębiorcą jest zobowiązany do przestrzegania zasad BHP zgodnie $\mathrm{z}$ art $207 \mathrm{kp}$. Rolnik prowadzący działalność gospodarczą w relacji z pomocnikiem jest traktowany jak „pracodawca” w ramach łączącego ich stosunku cywilnoprawnego. Art. 304 stanowi, iż w każdym przypadku zawarcia umowy na „innej podstawie niż stosunek pracy w (...) miejscu wyznaczonym przez pracodawcę" (czyli także w gospodarstwie), mają zastosowanie regulacje BHP.

5. Ewidencja czasu pracy. Kwestia ewidencjonowania czasu pracy pomocników stanowi oboczność do podstawowych typów umów o pracę, zlecenia, o świadczenie

16 Art. 63 ust. 2 Ustawy o ubezpieczeniu społecznym rolników, Dz. U.2017.0.2336, tekst jednolity Ustawa z dnia 20 grudnia 1990 r. o ubezpieczeniu społecznym rolników. 
usług. Gdy jednak zestawi się umowę o pomocy przy zbiorach ze wspomnianymi już wcześniej jedenastoma rodzajami umów cywilnoprawnych ${ }^{17}$, względem których nie stosuje się obowiązku ewidencjonowania czasu pracy, to nie sposób nie dostrzec, iż uregulowania te są analogiczne. Należy więc zauważyć, że umowa o pomocy przy zbiorach jest dwunastym typem wśród umów, w których zrezygnowano z ewidencjonowania czasu pracy. Legislator ocenił, iż w okresie szczególnego spiętrzenia prac niezasadne byłoby obciążanie rolników dodatkowym obowiązkiem prowadzenia ewidencji czasu pracy.

6. Przerwy i odpoczynki, tygodniowy wymiar pracy. Przed wszystkim należy zauważyć, iż umowa o pomocy przy zbiorach jest stosunkiem cywilnoprawnym, co expressis verbis artykułuje znowelizowana UoUSR. Stąd też rzeczona umowa nie podlega regulacjom w zakresie norm czasu pracy, przerw i odpoczynków. Ustawodawca nie regulując kwestii wymiaru odpoczynku, wymiaru przerw, wymiaru pracy, nie uczynił w tym zakresie wyjątku względem innych stosunków cywilnoprawnych (takich jak umowa zlecenie, umowa o świadczenie usług, umowa o dzieło etc. ${ }^{18}$ ). W tym miejscu można zauważyć, iż (pomimo dość często spotykanego przekonania środowisk reprezentujących interesy pracownicze) art. 8b Ustawy o minimalnym wynagrodzeniu za pracę, wobec pracodawców zatrudniających w formie stosunku cywilnoprawnego, nie określa wymagań monitorowania dziennego i tygodniowego wymiaru pracy, przerw i odpoczynków. Przedmiotowe uregulowania determinują jedynie oblig zsumowania wymiaru godzin pracy w celu ustalenia, czy iloraz kwoty wynagrodzenia brutto i wymiaru godzin pracy stanowi potwierdzenie wymiaru płacy minimalnej obowiązującej w danym roku. Z powyższego absolutnie natomiast nie wynika oblig dokumentowania wymiaru przerw i odpoczynków oraz dziennego i tygodniowego wymiaru pracy.

$\mathrm{W}$ polskim systemie prawnym istnieje jeden wyjątek od powyższej zasady i dotyczy on (w okrojonym zakresie) monitorowania wymiaru czasu pracy kierowców zawodowych $\mathrm{w}$ transporcie drogowym ${ }^{19}$. Należy jednak zaznaczyć, że wyjątek ten (wynikający ze szczególnego zagrożenia w ruchu lądowym) posiada źródło delegacji wprost z obligu implementacji do polskiego porządku prawnego unijnej „transportowej” Dyrektywy 2002/15 WE ${ }^{20}$. Analogicznych obowiązków nie wymaga się od jakiejkolwiek innej grupy pracowników i pracodawców.

Stawianie więc wyłącznie wobec rolników wymogu monitorowania (w ramach stosunków cywilnoprawnych) wymiaru czasu przerw i odpoczynków oraz dobowego wymiaru

17 Umowa zlecenia i umowa o świadczenie usług (,jeżeli o miejscu i czasie wykonania zlecenia lub świadczenia usług decyduje przyjmujący zlecenie lub świadczący usługi i przysługuje mu wyłącznie wynagrodzenie prowizyjne"); grupy umów dotyczących usług opiekuńczych i bytowych, realizowanych poprzez prowadzenie rodzinnego domu pomocy, umowa o dzieło.

${ }^{18}$ Grupa umów dotyczących usług opiekuńczych i bytowych, realizowanych poprzez prowadzenie rodzinnego domu pomocy, umowy dotyczące usług opieki domowej nad osobą niepełnosprawną, przewlekle chorą lub w podeszłym wieku.

19 Zob. rozdział 3a Ustawy o czasie pracy kierowców, Dz. U. 2001, Nr 125, poz. 1371.

${ }^{20}$ Dyrektywa 2002/15/WE Parlamentu Europejskiego i Rady z 11 marca 2002 r. w sprawie organizacji czasu pracy osób wykonujących czynności w trasie w zakresie transportu drogowego, https://eur-lex.europa.eu/legal-content/PL/TXT/PDF/?uri=CELEX:32002L0015\&from=PL (dostęp: 17.06.2018). 
pracy pozwalałoby zdać pytanie, czy aby nie stanowiłoby to przejawu nieuzasadnionej dyskryminacji rolników. Stąd też wydaje się zasadne, iż polski parlament zrezygnował z relatywizacji w zakresie obowiązków monitorowania czasu pracy i ustanowienia owego obligu wyłącznie wobec pracodawców/rolników, co w przeciwnym przypadku mogłoby zostać potraktowane jako naruszenie wielu konstytucyjnych zasad.

W tym miejscu można zauważyć jeszcze kwestię krótkotrwałego charakteru pracy pomocnika (formalnie maksymalnie $180 \mathrm{dni}$ w roku, ale w praktyce okresy spiętrzenia pracy trwają od kilku do kilkunastu dni). Należy zwrócić uwagę na taką okoliczność, że nawet w ramach uregulowań Kodeksu pracy dopuszczalny wymiar pracy nie wynosi 48 godzin pracy wraz z godzinami nadliczbowymi w tygodniu, lecz „przeciętnie 48 godzin w przyjętym okresie rozliczeniowym” wynoszącym nawet 4 miesiące. Oznacza to, iż w krótkich odcinakach czasu nawet Kodeks pracy wprost dopuszcza spiętrzenie czasu pracy. Trudno więc czynić zarzut wobec umowy cywilnoprawnej z dopuszczalności rozwiązania, które jest akceptowalne nawet na gruncie przepisów kp.

7. Zapewnienie napojów i posiłków dla pomocników. Uregulowania dotyczące umowy o pomocy przy zbiorach pomijają kwestię zapewnienia posiłków, ponieważ racjonalny legislator uznał za bezzasadne regulowanie zagadnień, które co do zasady nie występują w odniesieniu do regulowanego obszaru. Jakkolwiek zagadnienie zapewnienia wyżywienia oraz napojów jest ważne podczas pracy w skrajnie niskich i wysokich temperaturach, niemniej jednak można zauważyć, iż w praktyce pomocnicy przy zbiorach rekrutują się z sąsiadów posiadających własne domostwa w pobliżu pól oraz z pracowników spoza UE (głównie Ukraińców), którym na mocy odrębnych uregulowań rolnik zapewnia lokal mieszkalny ${ }^{21,22}$. Tak więc obie grupy pracowników co do zasady posiadają w pobliżu miejsca pracy warunki do zapewnienia we własnym zakresie dodatkowego wyżywienia oraz uzupełniania płynów. Nadmienić należy, że dodatkowo pomocnikami mogą być wyłącznie osoby pełnoletnie. Racjonalne wydaje się więc działanie legislatora zawężające uregulowania wyłącznie do faktycznie występujących okoliczności, czym zaspakaja się postulat emisji zwartego treścią i formą oraz czytelnego prawa.

8. Minimalne standardy narzędzi. Przedmiotowe zagadnienie zostało pominięte szczególnymi uregulowaniami z uwagi na charakter wykonywanych prac. Wobec braku kryteriów trudno bowiem byłoby w praktyce wykazać rolnikowi, że zapewniony został minimalny standard, np. kosza do zbioru płodów lub ręcznych narzędzi do pielenia. Nie można bowiem pozostać obojętnym na zakres czynności, które są wykonywane w ramach umowy o pomocy przy zbiorach. Są to praktycznie wyłącznie proste czynności natury manualnej, wykonywane przy zastosowaniu najprostszych i często niezmienionych od setek lat narzędzi (kosze, koszyczki, motyki, grabie, widły). Trudno dla tych urządzeń

${ }^{21}$ Znowelizowana Ustawa o promocji zatrudnienia i instytucjach rynku pracy, Dz. U. 2004, Nr 99, poz. 1001.

${ }^{22}$ Dyrektywa Parlamentu Europejskiego i Rady 2014/36/UE z dnia 26 lutego 2014 r. w sprawie warunków wjazdu i pobytu obywateli państw trzecich w celu zatrudnienia w charakterze pracownika sezonowego, https://eur-lex.europa.eu/legal-content/PL/TXT/PDF/?uri=CELEX:32014L0036\&from=pl (dostęp: 17.06.2018). 
określić standard i racjonalnie można przyjąć, że jest on wystarczający, skoro został pozytywnie zweryfikowany $\mathrm{w}$ trakcie ich wykorzystywania w ciągu co najmniej setek, a czasami tysięcy lat. Racjonalny legislator słusznie wyważył, czy występuje symetria pomiędzy wartością objętą ochroną a kosztami ochrony wartości, i na tej podstawie rozsądnie zrezygnował z określania minimalnego standardu tzw. urządzeń do zbioru, co należy ocenić w sposób aprobujący.

9. Normy dotyczące dźwigania. Także i w tym przypadku racjonalny legislator założył, iż zbędne jest tworzenie uregulowań w odniesieniu do okoliczności niewystępujących w praktyce gospodarstw rolnych objętych przedmiotowym rodzajem umowy. Punktem wyjścia dla takiego stanowiska jest zakres przedmiotowy prac przy zbiorach owoców i warzyw, chmielu, tytoniu i ziól. Nie sposób zakwestionować, że wśród wielu różnych prac w rolnictwie występują także prace ciężkie, lecz co do zasady nie w tych obszarach, które zostały objęte przedmiotem niniejszej umowy. Trudno bowiem mówić o jakimkolwiek obciążeniu przy zbiorach malin, truskawek (gdzie koszyki ważą około 2,5 kg), jabłek (gdzie metodyka zbioru co do zasady uniemożliwia dźwiganie) lub ziół, gdzie praca polega na pieleniu oraz odczyszczaniu i w ogóle nie występuje problem podnoszenia przedmiotów ciężkich. Nierozsądne wydawałoby się więc regulowanie zagadnień, co do których w ogóle nie występują stany faktyczne.

\section{Zabezpieczenia społeczne pomocników przy zbiorach}

Wprowadzenie do polskiego systemu prawnego umowy o pomocy przy zbiorach stanowi ogromny postęp w realizacji poziomu zabezpieczeń społecznych pracowników zatrudnionych w rolnictwie. Dotychczas w sektorze rolniczym niemalże wszyscy pracownicy przy zbiorach zatrudniani byli na podstawie wadliwie zawieranych umów o dzieło, które de facto pozbawione są gwarancji zabezpieczeń społecznych. Z tej perspektywy ustanowienie nowego typu umowy, zabezpieczonej w zakresie aż czterech świadczeń (składka: zdrowotna, wypadkowa, chorobowa i macierzyńska), stanowi ogromny postęp w kierunku zabezpieczenia interesu pracowników.

Wymiar świadczeń zgodnie ze znowelizowanym art. 80 ust. 3a posiada co do zasady charakter ruchomy w poszczególnych latach ${ }^{23}$. Oznacza to, że składka zdrowotna wyniesie (w bieżącym roku) 142,48 zł, natomiast składka na ubezpieczenie wypadkowe $42 \mathrm{zł}$.

23 „3a. Podstawę wymiaru składki na ubezpieczenie zdrowotne domowników rolników prowadzących działalność wyłącznie w zakresie działów specjalnych oraz pomocników rolników stanowi kwota 33,4\% przeciętnego miesięcznego wynagrodzenia $\mathrm{w}$ sektorze przedsiębiorstw $\mathrm{w}$ czwartym kwartale roku poprzedniego, włącznie z wypłatami z zysku, ogłaszanego przez Prezesa Głównego Urzędu Statystycznego w Dzienniku Urzędowym Rzeczypospolitej Polskiej «Monitor Polski». Składka od nowej podstawy wymiaru obowiązuje od dnia 1 kwietnia danego roku". Przeciętne miesięczne wynagrodzenie w sektorze przedsiębiorstw w czwartym kwartale roku 2017 włącznie z wypłatami z zysku wyniosło: 4739,91 zł; podstawa wymiaru składek wynosi zatem 1583,1299 zł. 
Umowa została zwolniona $\mathrm{z}$ obowiązku zabezpieczenia świadczeń emerytalno-rentowych, co zostało podyktowane jej krótkoterminowym charakterem (do $180 \mathrm{dni}$ w roku kalendarzowym) oraz faktem, iż znaczna część pracowników obywatelstwa polskiego, do których umowa jest adresowana (sąsiadów, studentów), podlega już ubezpieczeniu emerytalnemu z odrębnych źródeł. Można się zastanowić, czy nowe uregulowania nie czynią zbyt wiele w kierunku pokrycia kosztu składki zdrowotnej. $\mathrm{O}$ ile bowiem składka wypadkowa będzie pokrywana w ujęciu proporcjonalnym ${ }^{24}$ do wymiaru dni zatrudnienia, o tyle składka zdrowotna będzie świadczona w sposób zryczałtowany ${ }^{25}$, od każdej kolejnej zawartej umowy. Oznacza to w praktyce, że w warunkach silnej dynamiki zmiany zatrudnienia pomiędzy poszczególnymi rolnikami ten sam pracownik w obrębie jednego miesiąca może zostać wielokrotnie zabezpieczony składką ubezpieczenia zdrowotnego. Należy się spodziewać, iż z takiego rozwiązania będzie usatysfakcjonowana Kasa Rolniczego Ubezpieczenia Społecznego, która w warunkach zamiany umowy o dzieło na umowę o pomocy przy zbiorach spodziewa się wzrostu wpływów z tytułu ubezpieczeń nawet od 500 tys. pomocników ${ }^{26}$.

De lege ferenda można jednak rozważyć racjonalizację przedmiotowego rozwiązania i dopasowania go do specyfiki pracy pomocników, którzy u poszczególnych pracodawców pracują po kilka-kilkanaście dni. Mogłoby to odbarczyć z kosztów polskie rolnictwo i zwiększyć jego konkurencyjność, a także pozytywnie wpłynąć na obniżenie kosztów żywności.

\section{Opodatkowanie pracy}

Praca z tytułu umowy o pomocy przy zbiorach podlega nieco odmiennemu opodatkowaniu względem Polaków niż w odniesieniu do pomocników z Ukrainy. Praca polskich pracowników została opodatkowania stawką 19\%. Odmiennie ta sama kwestia została uregulowana w przypadku Ukraińców. Na podstawie bilateralnej umowy międzynarodowej ${ }^{27}$ dopóki Ukrainiec nie wykonuje w danym roku kalendarzowym pracy na terytorium Rzeczpospolitej, nie uiszcza podatku w Polsce (lecz jedynie na Ukrainie). Po przekroczeniu przez Ukraińca wymiaru 183 dni pracy w Polsce w roku kalendarzowym podatek będzie odprowadzany w polskim Urzędzie Skarbowym.

${ }^{24}$ Zob. art. 8 ust. 2a Ustawy o ubezpieczeniu społecznym rolników.

${ }_{25}$ Zob. art. 8 ust. 1 Ustawy o ubezpieczeniu społecznym rolników.

${ }^{26}$ Konferencja w Sękocinie k. Warszawy 24 marca 2018 r.

${ }^{27}$ Konwencja między Rządem Rzeczypospolitej Polskiej a Rządem Ukrainy w sprawie unikania podwójnego opodatkowania i zapobiegania uchylaniu się od opodatkowania w zakresie podatków od dochodu i majątku, sporządzona w Kijowie dnia 12 stycznia 1993 r., Dz. U. z 1994 r., Nr 63, poz. 269. 


\section{Krótkotrwały charakter umowy o pomocy przy zbiorach}

Umowa może zostać zawarta pomiędzy pomocnikiem a jednym lub wieloma rolnikami na maksymalny okres zaledwie 180 dni. Rolnik ma obowiązek odebrać od pomocnika oświadczenie o wymiarze dni już skonsumowanych przez pomocnika u innych rolników w danym roku kalendarzowym, co stanowi dodatkową formę zabezpieczenia interesów pracowniczych, przeciwdziałając długookresowemu zatrudnieniu bez ubezpieczenia emerytalno-rentowego.

\section{Godność pracy i odpoczynku pomocnika na gruncie praw człowieka oraz wartości Konstytucji RP}

Warto dokonać oceny zgodności przedmiotowych uregulowań z wartościami wyrażonymi na gruncie Konstytucji RP. Kierunek takiego dyskursu doktrynalnego zasugerował pośrednio związek zawodowy NSZZ „Solidarność” pracowników. Można z przedmiotowego stanowiska wykoncypować założenie o rzekomej potencjalnej niekonstytucyjności umowy o pomocy przy zbiorach ${ }^{28}$. Być może podstawę do założenia o potencjalnej niekonstytucyjności nowej umowy stanowi brak ustanowienia minimalnego wymiaru płacy minimalnej, brak określenia wymiaru pracy oraz odpoczynków. Prima facie mogłoby się wydawać, że każdy przypadek braku ustawowej gwarancji płacy minimalnej, wymiaru czasu pracy oraz odpoczynków narusza godność pracowniczą na gruncie praw człowieka oraz Konstytucji RP. Można więc zadać pytanie, dlaczego zarówno w polskim porządku prawnym, jak i w porządkach prawnych innych krajów znajdują się konstrukcje prawne (głównie cywilnoprawne) niezakreślające minimalnych ram wynagrodzenia minimalnego oraz norm pracy i odpoczynku.

Można wyrazić opinię, iż godność pracy i odpoczynku nie może być rozpatrywana w ujęciu jednowymiarowym, wyłącznie przez pryzmat godności pracownika z pominięciem godności pracodawcy oraz społeczeństwa.

Na straży praw człowieka (w kontekście godności pracy oraz godności odpoczynku) w naszym kraju stoi Konstytucja RP. Faktem niezaprzeczalnym jest niedopuszczalność czerpania korzyści z prawa stanowionego, które naruszałoby podstawowe wartości wynikające z praw człowieka, takich jak godność ludzka - która usytuowana została w hierarchii praw człowieka ponad prawem stanowionym. Nie sposób kwestionować ugruntowanego w doktrynie poglądu, iż godność (jako element praw człowieka oraz wartość w ujęciu filozoficznym) jest niezależna od czyichkolwiek przekonań, ponieważ przyjmuje się słusznie w doktrynie, $\dot{z e}^{29}$ : „niezależnie od formalnie obowiązującego prawa

${ }^{28}$ Zob. List Przewodniczącego NSZZ „Solidarność” Piotra Dudy do Prezydenta RP Andrzeja Dudy, http://www.solidarnosc.org.pl/aktualnosci/wiadomosci/kraj/item/17668-solidarnosc-apeluje-do-prezydenta-w-sprawie-parobkow (dostęp: 17.06.2018r).

29 Zob. M. Piechowiak, Filozofia praw człowieka. Prawa człowieka w świetle ich międzynarodowej ochrony, Lublin 1999. 
pozytywnego człowiek ma pewne fundamentalne prawa (...) prawo stanowione może być prawem zbrodniczym, «ustawowym bezprawiem», jak to określił Gustav Radbruch"30.

Niemniej jednak wyraźnie wskazuje się w doktrynie praw człowieka, iż odrzucenie normy prawa pozytywnego na rzecz reguł praw człowieka może nastąpić wyłącznie po przeanalizowaniu konkretnego przypadku w kontekście uprzedniego ustalenia, czy i dlaczego dana norma ewentualnie narusza prawa człowieka. Poszanowanie praw człowieka nie polega na arbitralnym odrzuceniu treści prawa stanowionego tylko dlatego, iż posiada się odrębny światopogląd na daną sprawę.

Przenosząc powyższe ustalenie na grunt oceny konstytucyjności umowy o pomocy przy zbiorach, można ocenić, iż poszanowanie godności pracowniczej pomocnika przy zbiorach nie polega na uproszczonym, arbitralnym odrzuceniu postanowień uregulowań, które nie ustanawiają wymiaru płacy minimalnej oraz wymiaru pracy i odpoczynku.

Ocena poszanowania godności pomocnika przy zbiorach polega na ustaleniu, czy norma regulująca jego status prawny nie powstała $\mathrm{z}$ naruszeniem zasad konstytucyjnych, a więc czy aby np. nie powstała w państwie totalitarnym, traktującym obywateli w sposób przedmiotowy i czy nie traktuje pomocników w sposób gorszy od innych pracowników/ obywateli lub czy też nie ogranicza prawa pracownika/pomocnika przy zbiorach do wyboru innej pracy.

Niedopuszczalne jest wywodzenie skutków z poszczególnych praw człowieka (np. w zakresie oceny godności pracy i odpoczynku) w oderwaniu od analizy poszanowania wartości względem wszystkich „stron”, którymi w tym przypadku są: pracownik, pracodawca i społeczeństwo (państwo). Działanie takie stanowi zaprzeczenie idei realizacji godności w rozumieniu praw człowieka. Rozumienie praw człowieka (godności) i ocena o konstytucyjności jedynie na poziomie reprezentacji interesów jednej ze „stron” lub lepiej ujmując - jednego z ich beneficjentów (pracownika) z pominięciem pozostałych adresatów normy (pracodawcy, społeczeństwa) skutkowałyby afirmacją karykaturalnego obrazu praw człowieka.

Reasumując, w analizie poszanowania zgodności na płaszczyźnie uregulowań ustanawiających umowę o pomocy przy zbiorach w kontekście uregulowań Ustawy Zasadniczej (która jest wyrazicielem praw człowieka w Rzeczpospolitej Polskiej) należy dokonać oceny w następującym zakresie: (a) wolności prezentowania własnego stanowiska w trakcie procesu ustawodawczego, a w szczególności w kontekście reprezentatywności w parlamencie zarówno przedstawicieli pracodawców, jak i pracowników; (b) wyboru miejsca i warunków pracy; (c) wolności wyboru pracy; (d) wolności kształtowania stosunku cywilnoprawnego; (e) symetrii pomiędzy interesami pracownika (pomocnika), pracodawcy (rolnika) i społeczeństwa; (f) ekwiwalentności uregulowań dotyczących umowy o pomocy względem innych podobnych uregulowań występujących w polskim porządku prawnym.

${ }^{30}$ G. Radbruch, Gesetzliches Unrecht und übergesetzliches Recht, w: Tenże, Der Mensch im Recht, Göttingen 1961, s. 111-124. 
Odnosząc się do poszczególnych kwestii, zasadne jest wyrażenie oceny, iż:

- z całą pewnością Rzeczpospolita Polska nie posiada ustroju totalitarnego;

- interesy oraz racje zarówno pracodawców, jak i pracowników oraz ich związków zawodowych, stowarzyszeń, były (w procesie uchwalania umowy o pomocy przy zbiorach) w polskim parlamencie reprezentowane na wszystkich etapach stanowienia prawa za pośrednictwem posłów i senatorów. Dodatkowo należy zaznaczyć, iż np. parlamentarzyści NSZZ „Solidarność” głosowali w parlamencie „za uchwaleniem” umowy o pomocy przy zbiorach, co stanowi pośredni dowód transparentności oraz akceptacji nowej umowy przez środowiska zarówno pracownicze, jak i pracodawców;

- uczestnictwo w konsultacjach społecznych miało charakter otwarty i transparentny, a prace trwały wiele miesięcy;

- strony umowy o pomocy przy zbiorach mają zagwarantowaną swobodę wyboru formy kontraktu (pomiędzy cywilnoprawną umową o pomocy przy zbiorach a stosunkiem pracy), jak również swobodę kształtowania samej treści kontraktu umowy o pomocy przy zbiorach;

- występuje ekwiwalentność rozwiązań pomiędzy uregulowaniami umowy o pomocy przy zbiorach a wspomnianymi wcześniej jedenastoma innymi typami umów cywilnoprawnych w zakresie płacy minimalnej, wymiaru godzin pracy i odpoczynków;

- występuje symetria oraz wyważenie racji w ochronie wartości na osi: pracownik (pomocnik) pracodawca (rolnik) - społeczeństwo (interes społeczny).

Nie sposób nie dostrzegać, iż immanentnymi filarami każdej państwowości są: ochrona granic, autonomia monetarna oraz zdolność do wyżywienia obywateli na terytorium państwa. W tym kontekście uzasadnione wydaje się akcentowanie szczególnego rodzaju roli umowy, jaką ustawodawca zabezpiecza interes nie tylko rolników, lecz także państwowości.

Nie bez znaczenia jest także to, że umowa ma zastosowanie wyłącznie do wybranych gałęzi rolnictwa i wyłącznie wybranych rodzajów czynności, które mogą zostać wykonane wyłącznie siłą ludzkich rąk w warunkach nadzwyczajnego, okresowego spiętrzenia prac rolniczych oraz których brak skutkowałby zniszczeniem upraw bądź też nielegalnym zatrudnieniem pracowników, co $\mathrm{w}$ każdym $\mathrm{z}$ tych przypadków należałoby ocenić krytycznie jako naruszenie wartości nadrzędnych (społecznych, państwowych) nad interesami jednostki.

Prezentowanie poglądu o rzekomej niekonstytucyjności umowy o pomocy przy zbiorach tylko na podstawie stwierdzenia braku ustanowienia płacy minimalnej oraz wymiaru pracy z pominięciem szczególnego charakteru specyfikacji prac $\mathrm{w}$ rolnictwie oraz z pominięciem interesu i bezpieczeństwa żywnościowego państwa, a także z pominięciem rozważań nad praworządnością $\mathrm{w}$ kontekście eliminacji za sprawą umowy o pomocy nieprawidłowo wykorzystywanych umów o dzieło, z pominięciem faktu zwiększenia poziomu zabezpieczeń społecznych pomocników względem dotychczasowych form zatrudnienia - wydaje się nieuzasadnionym powoływaniem się na naruszenie konstytucyjnej wartości godności pomocników przy zbiorach. Tak rozumiana godność może zostać potraktowana jako uzasadnienie postaw egocentrycznych, a wręcz postaw 
„agresywnych” wobec innych podmiotów. Oznaczałoby to bowiem (z czym niesłychanie trudno się zgodzić), że „godność” utożsamia się z „wygodą" jednej ze stron ${ }^{31}$ i każda niewygoda uzasadnia prawo do „godnej agresji” lub do „agresji w imię godności” wobec tych, którzy owej wygody nie zapewnili w oczekiwanym zakresie, z pominięciem realiów uwarunkowań branży, pogody (ogólnie vis maior), sytuacji ekonomicznej rolników utrzymujących rodziny wyłącznie z pracy rolniczej.

Immanentną częścią godności pracy i odpoczynku jest „wolność” jednostki. Nie jest to oczywiście wolność bezwarunkowa i bezgraniczna, niemniej jednak wydaje się, iż jedną z cech warunkującą godność jednostki w jej egzystencji społecznej i gospodarczej jest wolność wyboru ${ }^{32}$.

Tam, gdzie brak jest wolności w gospodarczych relacjach społecznych, zachodzi podejrzenie dysfunkcjonalności godności. Stąd też w ocenie w zakresie godności pracy pomocników przy zbiorach istotna jest analiza realizacji uprawnienia do dokonywania przez pracownika/pomocnika wolnych wyborów w zakresie wyboru takiej lub innej formy zatrudnienia oraz pracy.

W świetle powyższego trudno podzielić pogląd o niekonstytucyjności uregulowań dotyczących umowy o pomocy przy zbiorach, skoro nie sposób wykazać na płaszczyźnie praw człowieka naruszenia wartości wolności wyboru, symetrii zabezpieczenia interesów państwa i jednostki, braterstwa, transparentności i reprezentacji w procesie legislacyjnym przedstawicieli pracodawców oraz pracowników.

\section{Konsultacje społeczne}

Nowy rodzaj umowy jest wynikiem bardzo długiego, ponadrocznego okresu konsultacji społecznych. Pierwsze prace i rozmowy nad propozycjami opracowania przedmiotowej umowy rozpoczęły się w marcu 2017 r. w Ministerstwie Rodziny, Pracy i Polityki Społecznej, a następnie były kontynuowane w Ministerstwie Rolnictwa i Rozwoju Wsi. W pracach brali udział przedstawiciele NSZZ Rolników Indywidualnych „Solidarność, kilku stowarzyszeń rolniczych, parlamentarzyści kilku opcji politycznych, przedstawiciele z Ośrodków Doradztwa Rolniczego, przedstawiciele KRUS, Ministerstwa Spraw Zagranicznych, Ministerstwa Sprawiedliwości. Konsultacje miały długotrwały i bardzo szeroki zakres.

$\mathrm{W}$ procesie długotrwałych negocjacji i konsultacji społecznych oraz międzyresortowych udało się wypracować optymalny obecnie kształt umowy o pomocy przy zbiorach, dopasowanej do możliwości, realiów i potrzeb rolnictwa, z jednoczesną dbałością o zabezpieczenie interesów pracowniczych oraz Skarbu Państwa, przy poszanowaniu zasad praworządności, poprzez wypracowanie legalnej umowy, która zastąpi nieprawidłowo wykorzystywane umowy o dzieło.

${ }^{31}$ Podstawa podstaw. O godności osoby ludzkiej, https://www.youtube.com/watch?v=b7LaL4qcP2w (dostęp: 17.06.2018).

${ }^{32}$ M. Bierdiajew, Królestwo Ducha i Królestwo Cezara, Kęty 2003, s. 53-60. 
Umowa o pomocy przy zbiorach w wielu elementach stanowi swoisty „wyłom” w dotychczasowym kierunku protekcjonizmu państwa wobec pracowników na gruncie regulacji prawa pracy lub prawa cywilnego. Rezygnacja z protekcjonizmu odzwierciedla jednak szczególny charakter i rolę rolnictwa jako jednego z trzech fundamentalnych filarów państwowości (oprócz własnego systemu monetarnego i zdolności zabezpieczenia granic), co znajduje swoje oparcie historycznie w Traktacie rzymskim ${ }^{33}$ obejmującym rolnictwo szczególną ochroną.

Umowa o pomocy przy zbiorach stanowi więc egzemplifikację kierunku wyznaczonego 60 lat temu na gruncie prawa wspólnotowego.

\section{Bibliografia}

Bierdiajew M., Królestwo Ducha i Królestwo Cezara, Kęty 2003.

Dyrektywa 2002/15/WE Parlamentu Europejskiego i Rady z 11 marca 2002 r. w sprawie organizacji czasu pracy osób wykonujących czynności w trasie w zakresie transportu drogowego.

Konwencja między Rządem Rzeczypospolitej Polskiej a Rządem Ukrainy w sprawie unikania podwójnego opodatkowania i zapobiegania uchylaniu się od opodatkowania w zakresie podatków od dochodu i majątku, sporządzona w Kijowie dnia 12 stycznia 1993 r., Dz. U. z 1994 r., Nr 63, poz. 269.

List Przewodniczącego NSZZ „Solidarność” Piotra Dudy do Prezydenta RP Andrzeja Dudy, http://www.solidarnosc.org.pl/aktualnosci/wiadomosci/kraj/item/17668-solidarnosc-apeluje-do-prezydenta-w-sprawie-parobkow (dostęp: 17.06.2018).

Piechowiak M., Filozofia praw człowieka. Prawa człowieka w świetle ich międzynarodowej ochrony, Lublin 1999.

Podstawa podstaw. O godności osoby ludzkiej, https://www.youtube.com/watch?v=b7LaL4qcP2w (dostęp: 17.06.2018).

Radbruch G., Gesetzliches Unrecht und übergesetzliches Recht, w: Tenże, Der Mensch im Recht, Göttingen 1961

Ustawa Kodeks pracy, Dz. U. 1974, Nr 24, poz. 141.

Ustawa o czasie pracy kierowców, Dz. U. 2001, Nr 125, poz. 1371.

Ustawa o promocji zatrudnienia i instytucjach rynku pracy, Dz. U. 2004, Nr 99, poz. 1001.

Ustawa z dnia 13 kwietnia 2018 r. o zmianie ustawy o ubezpieczeniu społecznym rolników oraz niektórych innych ustaw, Dz. U. 2018, poz. 858.

Ustawa z dnia 15 września 2000 r. o grupach producentów rolnych i ich związkach oraz o zmianie innych ustaw, Dz. U. 2000, Nr 88, poz. 983.

Ustawa z dnia 23 kwietnia 1964 r. Kodeks cywilny, Dz. U. 1964, Nr 16, poz. 93.

Ustawa z dnia 12 marca 2004 r. o pomocy społecznej, Dz. U. z 2016 r., poz. 930.

33 Traktat rzymski z 25 marca 1957 r. ustanawiający Europejską Wspólnotę Gospodarczą, obowiązujący od 1 stycznia 1958 r., regulujący między innymi zasady wspólnej polityki rolnej. 